\title{
ROZWAŻANIA NAD PRZYDATNOŚCIĄ POJĘCIA BLĘDU MADYCZNEGO DLA USTALENIA ODPOWIEDZIALNOŚCI KARNEJ LEKARZA ZA NEGATYWNE SKUTKI DLA ŻYCIA I ZDROWIA PACJENTA POWSTALE W PROCESIE LECZENIA NA GRUNCIE POLSKIEJ LITERATURY I ORZECZNICTWA
}

\begin{abstract}
Streszczenie. Celem opracowania jest ukazanie ewolucji rozumienia pojęcia błędu medycznego, w tym pojawiających się wokół tej kwestii rozbieżności stanowisk i wątpliwości interpretacyjnych oraz ocena przydatności stosowania tego terminu dla ustalenia odpowiedzialności karnej lekarza za negatywne skutki dla życia i zdrowia pacjenta powstałe w procesie leczenia. Rozważania koncentrują się na dwóch kwestiach, a mianowicie na ukazaniu poglądów doktryny i orzecznictwa na temat błędu medycznego, a następnie na umiejscowieniu tego pojęcia w strukturze przestępstwa skutkowego charakteryzującego się nieumyślnością. Ocenie poddana jest w szczególności relacja między błędem medycznym a naruszeniem zasad postępowania $\mathrm{z}$ dobrem prawnym, na gruncie nieumyślności zwanych regułami ostrożności wymaganej w danych okolicznościach. W końcowej części rozważań zaprezentowane są argumenty przeciwko uznaniu błędu medycznego za odrębną przesłankę odpowiedzialności karnej za przestępstwa skutkowe popełnione w związku z udzielaniem świadczeń zdrowotnych, jak również fakty przemawiające za rezygnacją z posługiwania się tym terminem na rzecz szerszej kategorii, jaką jest naruszenie reguł ostrożności.
\end{abstract}

Słowa kluczowe: błąd medyczny, reguły ostrożności, aktualna wiedza medyczna, odpowiedzialność karna lekarza, świadczenie zdrowotne.

\section{WPROWADZENIE}

Zainteresowanie problematyką odpowiedzialności za negatywne skutki dla życia i zdrowia pacjenta powstałe w procesie leczenia zdaje się nie słabnąć od czasów ukształtowania się zawodu lekarza. Jednakże z początkiem XX wieku notuje się szczególną jego intensyfikację. Od tego czasu pojęcie błędu medycznego, powszechnie łączone z kwestią ustalania odpowiedzialności zawodowej, cywilnej i karnej lekarza, stało się przedmiotem licznych rozważań w polskiej literaturze i orzecznictwie. Głównej motywacji do wyczerpującego opisania pojęcia błędu medycznego można upatrywać w braku jego legalnej definicji. Fakt

* Uniwersytet Łódzki, Wydział Prawa i Administracji, Katedra Prawa Karnego, aleksandra. m.dabek@gmail.com 
ten w konsekwencji zaważył także na powstaniu rozbieżności w rozumieniu owego pojęcia, używanego $\mathrm{z}$ czasem $\mathrm{w}$ różnych znaczeniach $\mathrm{w}$ języku potocznym, literaturze prawniczej i medycznej, opiniach biegłych oraz szeroko rozumianej praktyce wymiaru sprawiedliwości. Celem niniejszego opracowania jest ukazanie ewolucji rozumienia pojęcia błędu medycznego, w tym pojawiających się wokół tej kwestii rozbieżności stanowisk i wątpliwości interpretacyjnych oraz ocena przydatności stosowania tego pojęcia na potrzeby ustalenia odpowiedzialności karnej lekarza za negatywne skutki dla życia i zdrowia pacjenta powstałe w procesie leczenia.

\section{BLĄD MEDYCZNY W LITERATURZE I ORZECZNICTWIE}

Rozważania o istocie błędu medycznego wypada rozpocząć od wskazania, że w literaturze i orzecznictwie nie ma zgodności, co obejmuje to pojęcie $\mathrm{i}$ jaki jest zakres jego zastosowania, ani nawet $\mathrm{w}$ jakim brzmieniu powinno ono funkcjonować. Obok pojęcia błędu medycznego stosowane są bowiem takie terminy, jak błąd w sztuce medycznej, błąd lekarski, błąd w sztuce lekarskiej, błąd wiedzy lekarskiej, błąd w stosowaniu wiedzy lekarskiej czy też błąd leczniczy ${ }^{1}$. Pozostawiając w tej części rozważań na uboczu ostateczną ocenę przydatności stosowania pojęcia błędu medycznego dla ustalenia odpowiedzialności karnej - niezależnie od nadanego mu brzmienia - należy uznać stosowanie każdego z tych określeń za dopuszczalne, o ile używa się go mając na uwadze jego zakres pojęciowy ${ }^{2}$. Błąd lekarski, błąd w sztuce lekarskiej i błąd w stosowaniu wiedzy lekarskiej są pojęciami stosunkowo wąskimi w aspekcie podmiotowym, jako że odnoszą się jedynie do lekarza, podczas gdy pojęcie błędu medycznego lub błędu w sztuce medycznej może znaleźć zastosowanie także przy ocenie działalności przedstawicieli innych zawodów medycznych, przykładowo pielęgniarki, położnej albo ratownika medycznego, biorących udział w udzielaniu świadczeń zdrowotnych samodzielnie bądź w zespołowym działaniu z lekarzem. Z kolei termin błąd wiedzy lekarskiej, lub też błąd w stosowaniu wiedzy lekarskiej, koncentruje się na aspekcie naruszenia przez lekarza wskazań aktualnej wiedzy medycznej, pozostawiając poza nawiasem przypadki niedochowania innych reguł ostrożności, chociażby

${ }^{1}$ Przykładowo pojęciem ,błędu sztuki” (lekarskiej lub medycznej) posługują się: Wanatowska, Kulesza (1988, 25 i n.); Nestorowicz (2001, 145 i n.); Kędziora (2009, 194). Za rezygnacją z pojęcia „błędu sztuki” na rzecz „błędu medycznego” opowiadają się: Marek (1999, 36-38 i 83); Kubiak (2012, 317-318); Sroka (2013, 457 i n.). Określenia „błąd lekarski” używa Sośniak (1968, 64). Zwolennikiem terminów: „błąd wiedzy lekarskiej” i „błąd w stosowaniu wiedzy lekarskiej” jest Baran (1996, 254).

${ }^{2}$ W tym tonie wypowiada się Kędziora $(2009,194)$. Zdaniem autorki istotna jest nie sama nazwa, ale faktyczna treść, którą zawiera dane pojęcie, a wybór terminu jest tylko kwestią konwencji. 
wymogu należytej staranności. Ograniczone zastosowanie ma też pojęcie błędu leczniczego, gdyż nie obejmuje swym zakresem błędów popełnionych podczas wykonywania czynności nieterapeutycznych, którymi są przykładowo przeprowadzenie eksperymentu badawczego, zapłodnienie pozaustrojowe oraz eksplantacja ex vivo (Kubiak 2012, 318). Z pewną ostrożnością należy podchodzić także do stosowania terminu błędu w sztuce lekarskiej czy też medycznej, gdyż taka konstrukcja pojęciowa akcentuje elementy subiektywne, podczas gdy w doktrynie ugruntował się pogląd o obiektywnym charakterze błędu medycznego, o czym szerzej będzie mowa w dalszej części rozważań. W tym miejscu warto jednak wspomnieć, że jako argument przeciw odwoływaniu się do słowa „sztuka” w kontekście błędu medycznego podaje się fakt, że wykonywanie zawodu lekarza polega na praktycznym wykorzystaniu osiagnięć medycyny, będącej nauką ścisłą, zajmującą się badaniem rzeczywistości, a tam, gdzie pojawiają się oparte na dowodach naukowych zasady postępowania, medycyna traci charakter sztuki ${ }^{3}$. Z kolei wedle zwolenników posługiwania się tym określeniem, wiele złożonych czynności medycznych wymaga posiadania indywidualnych zdolności, jak chociażby zręczność manualna, bystrość obserwacji, pamięć w diagnostyce oraz swoista intuicja, stąd odwoływanie się w tych przypadkach do pojęcia sztuki - rozumianej jako biegłość, kunszt, maestria nie powinno budzić wątpliwości ${ }^{4}$. Idąc jednak dalej tym tokiem rozumowania, można dojść do wniosku, że błąd w sztuce może być popełniony tylko przez osobę, która posiada owe, mogące być uznane za sztukę, nadzwyczajne umiejętności, a zatem posługiwanie się pojęciem błędu w sztuce wydaje się uprawnione tylko w odniesieniu do tych lekarzy, w których działalności, obok ścisłej wiedzy medycznej, występują również wspomniane elementy sztuki (Popielski $1963,254)^{5}$. Co więcej, poza zakresem pojęcia w tym ujęciu pozostaną sytuacje, w których podczas wykonywania czynności medycznej dojdzie do zwyczajnego, ordynarnego zaniedbania, które nie ma nic wspólnego ze sferą sztuki (Filar 2000, 109) ${ }^{6}$. Należy ponadto zaznaczyć, że wielu autorów zajmujących się problematyką błędów medycznych przeprowadza ich klasyfikację, w związku

${ }^{3}$ Zasadność posługiwania się pojęciem błędu w sztuce kwestionują: Baran (1996, 254); Boratyńska, Konieczniak (1999, 55); Marek (1999, 36-38 i 83); Filar (2000, 108 i n.); Sroka (2013, $457 \mathrm{i} \mathrm{n}$.).

${ }^{4}$ Ten punkt widzenia prezentują: Popielski (1963, 253 i n.); Rejman (1991, 169 i n.); Liszewska (1998, 24 i n.). Szczególnym zwolennikiem pojęcia błędu w sztuce jest Sawicki (1965, 125). Autor podkreśla, że ,należy zdać sobie sprawę i z tego, że rozpoznanie choroby osiąga lekarz często nie drogą logicznego rozumowania, lecz przez niezwykły dar, w jaki natura go wyposażyła, do wczucia się w położenie chorego, przez akt wspaniałej intuicji, którą nie każdy dysponuje w równym stopniu, a która zrównuje ten piękny zawód z wielką - prawdziwą sztuką".

${ }^{5}$ Zauważa to również Liszewska (1994, 134-137).

${ }^{6}$ Zdaniem autora przykładowo zaszycie w polu operacyjnym narzędzia chirurgicznego nie stanowi żadnego błędu w sztuce, lecz zwykłe, ordynarne zaniedbanie, które pozostaje w ogóle poza sferą rozważań w płaszczyźnie sztuki lekarskiej. 
z czym w literaturze można spotkać także takie pojęcia, jak błąd: diagnostyczny, terapeutyczny, techniczny, organizacyjny, zgodnie z systematyką przyjętą przez A. Zolla, A. Liszewską, M. Filara i R. Kędziorę, a także błąd: rozpoznania, rokowania, terapii, stosownie do podziału zaproponowanego przez M. Sośniaka, jak również błąd: decyzyjny, wykonawczy, organizacyjny, opiniodawczy, wedle klasyfikacji zaproponowanej przez Z. Marka ${ }^{7}$. Przy czym wart podkreślenia jest fakt, że nie zawsze owe pojęcia rozumiane są przez powołanych autorów jako błędy w ścisłym tego słowa znaczeniu. Na potrzeby niniejszego opracowania należy opowiedzieć się za najbardziej uniwersalnym określeniem, a mianowicie za używaniem pojęcia „błąd medyczny”.

Przechodząc od rozważań na płaszczyźnie terminologicznej do przybliżenia, jak ewoluowało postrzeganie pojęcia błędu medycznego w polskiej literaturze i orzecznictwie, należy zaznaczyć, że początkowo w doktrynie dominowało przekonanie o jego subiektywnym charakterze, sprowadzające się do identyfikacji błędu medycznego z zawinieniem ${ }^{8}$. Wedle tej teorii fakt popełnienia błędu medycznego niejako automatycznie przesądzał o winie lekarza. Rozumowanie to opierało się na założeniu, że lekarz powinien znać zasady postępowania medycznego, jeżeli więc dokonuje zabiegu $\mathrm{z}$ ich naruszeniem, to tym samym narusza także ciążący na nim obowiązek znajomości tych zasad, co w konsekwencji czyni go winnym spowodowanych na tej drodze skutków. Każdy błąd medyczny, w tym ujęciu, dowodził zatem sam przez się winy dokonującego zabiegu i co za tym idzie - przesądzal o odpowiedzialności karnej9. Nawet dla późniejszych rozwiązań proponowanych na gruncie tej koncepcji - których autorzy zdawali się dostrzegać, że nie każdy błąd musi prowadzić do odpowiedzialności karnej - właściwe było przenikanie się, w ramach kryteriów jego oceny, przesłanek bezprawności z okolicznościami o charakterze zindywidualizowanym, które powinny być rozpatrywane na płaszczyźnie zawinienia, zatem zupełnie odrębnie, a nie jedynie na marginesie ustalania bezprawności czynu ${ }^{10}$. Dopiero z czasem zaczęto postrzegać naruszenie zasad postępowania medycznego $\mathrm{w}$ kategoriach obiektywnych, oddzielając elementy struktury przestępstwa o charakterze obiektywnym, decydujące o bezprawności, od elementów o charakterze subiektywnym, właściwych sferze zawinienia. Pierwszym autorem, który wprowadził na grunt polskiej nauki koncepcję wyraźnego rozgraniczenia pomiędzy błędem a winą, był J. Sawicki, postrzegający błąd medyczny jako „kategorię obiektywną, zależną wyłącznie od stanu wiedzy medycznej na danym

${ }^{7}$ Zob. Zoll (1988, 63-77); Liszewska (1998, 153-198); Filar (2000, 115-129); Kędziora (2009, 207-229); Sośniak (1968, 100-113); Marek (1999, 83-104).

${ }^{8}$ W tym tonie wypowiadają się: Wachholz $(1925,429)$; Ruff $(1929,10)$; Cyprian, Asłanowicz (1949, 52-53); Grzywo-Dąbrowski (1958, 12); Popielski (1963, 254 i n.).

${ }^{9}$ Szerzej na ten temat pisze Sawicki $(1965,63)$. Stanowisko takie w polskiej literaturze zajmował Ruff $(1929,10)$.

${ }^{10}$ Tak: Wachholz (1925, 429); Cyprian, Asłanowicz (1949, 53); Grzywo-Dą̨browski (1958, 12); Popielski (1963, 254 i n.). 
etapie rozwoju" (Sawicki 1954, 991 i n.) ${ }^{11}$. Zdaniem autora, ustalenie, że doszło do popełnienia błędu medycznego, nie daje samo przez się podstawy do uznania winy lekarza za wykazana. „Ustalenie powyższe stanowi kategorię wyłącznie obiektywną. Nie ma i nie może być związku pomiędzy tym ustaleniem a właściwościami dokonującego zabiegu. Młodość, niedoświadczenie lekarza, wyjątkowość sytuacji, w której dokonuje się zabiegu - wszystkie te okoliczności stanowią element subiektywny i podlegają badaniu dopiero w związku z przypisaniem winy dokonującemu zabiegu" (Sawicki 1958, 104 i n.) ${ }^{12}$. Koncepcja obiektywnego charakteru błędu medycznego znalazła odzwierciedlenie w orzecznictwie ${ }^{13}$, w którym zaczęto wyraźnie akcentować potrzebę ustalenia w pierwszej kolejności, czy doszło do naruszenia zasad postępowania medycznego, a dopiero na dalszym etapie, odrębnego dokonania wartościowania zachowania sprawcy tego naruszenia. $\mathrm{Z}$ prezentowanej przez lata linii orzeczniczej wyłamał się wyrok SN z 16.1.1974 r. (III KR 311/73, LEX $\mathrm{Nr}$ 21606), odwołujący się do koncepcji subiektywnej, który spotkał się jednak z wyraźną krytyką ze strony doktryny ${ }^{14}$. Obecnie w literaturze ${ }^{15}$ i orzecznictwie ${ }^{16}$ zgodnie postrzega się błąd medyczny jako kategorię obiektywną. Niemniej przyjęcie tego poglądu implikuje kolejny problem interpretacyjny, związany z relacją tego pojęcia do naruszenia zasad postępowania $\mathrm{z}$ dobrem prawnym, określanych także - zwłaszcza na gruncie nieumyślności - mianem reguł ostrożności wymaganych w danych okolicznościach. Przed przejściem jednak do rozstrzygnięcia tej kwestii warto nakreślić ramy znaczeniowe obu tych kategorii.

Jak wcześniej wspomniano, błąd medyczny nie jest pojęciem ustawowym, a jego definicja formułowana była w literaturze i orzecznictwie, co siłą rzeczy stało się podatnym gruntem dla powstania rozbieżności w rozumieniu tego terminu. Analiza literatury przedmiotu skłania do wniosku, że autorzy różnorodnie określają zakres owego pojęcia. Stosunkowo wąsko rozumie je J. Sawicki, który postrzega „błąd sztuki lekarskiej” jako „kategorię obiektywną, zależną wyłącznie od stanu wiedzy medycznej na danym etapie rozwoju" (Sawicki 1954, 1003) ${ }^{17}$.

${ }^{11}$ Por. też: Sawicki (1958, 104 i n.); Sawicki $(1965,68)$.

${ }^{12}$ Por. też: Sawicki $(1965,68$ i 73$)$.

${ }^{13}$ Por. wyr. SN z 16.5.1953 r. (I K 77/53, OSNCK 1953, Nr 4, poz. 55); wyr. SN z 19.8.1963 r. (I K 295/53, Państwo i Prawo 1954, Nr 2, s. 381); wyr. SN z 3.12.1958 r. (IV K 28/58, Państwo i Prawo 1960, Nr 1, s. 200); wyr. SN z 30.9.1960 r. (II K 675/60, OSNPG 1961, Nr 1, poz. 1); uchw. SN z 23.3.1961 r. (VI KO 13/61, OSNCK 1961, Nr 3, poz. 3); wyr. SN z 8.9.1973 r. (I KR 116/72, OSNKW 1974, Nr 2, poz. 26); orzecznictwo powołane przez: Sawicki (1965, 69 i n.).

${ }^{14}$ Tak: Buchała $(1974,1583)$; Liszewska $(1998,18)$.

15 Tak: Sośniak (1968, 74-75); Buchała (1963, 89); Wanatowska, Kulesza (1988, 25 i n.); Zoll (1988, 53-54); Rejman (1991, 212 i n.); Liszewska (1998, 18); Filar (2000, 109); Nesterowicz (2001, 145); Kędziora $(2009,196)$; Sroka $(2013,460)$.

${ }^{16}$ Tak: wyr. SN z 29.4.1994 r. (WR 70/94, OSNKW 1994, Nr 11-12, poz. 70); wyr. SN z 10.12.2002 r. (V KK 33/02, LEX Nr 75498); wyr. SN z 12.2.2013 r. (II KK 124/12, LEX $\mathrm{Nr}$ 1277697).

${ }^{17}$ Por. też: Sawicki (1958, 104); Sawicki $(1965,68)$. 
Z kolei E. Baran twierdzi, że „błąd sztuki należy rozumieć jako błąd w stosowaniu wiedzy lekarskiej" (Baran 1996, 254). Stanowiska te niejako łączy w całość M. Filar, w którego ocenie „błędem w sztuce lekarskiej” jest „,naruszenie przez lekarza wykonującego czynność leczniczą obowiązującego w relacji do tej czynności zespołu reguł i zasad postępowania zawodowego, których źródłem jest wiedza i praktyka medyczna" (Filar 2000, 110). Autor poszerza zatem definicję błędu medycznego - rozumianego jako zachowanie sprzeczne $\mathrm{z}$ aktualną wiedzą medyczną - o naruszenie zasad, których źródłem jest doświadczenie zawodowe lekarza, wynikające z praktycznego zastosowania owej wiedzy medycznej. W tym tonie utrzymana jest także wypowiedź R. Kędziory, która ujmuje „błąd w sztuce medycznej” jako „postępowanie lekarza sprzeczne z powszechnymi, obowiązującymi go w odniesieniu do konkretnej czynności medycznej zasadami postępowania zawodowego, mającymi swoją podstawę w nauce i praktyce medycznej" (Kędziora 2009, 199 i 200). Autorka wnioskując a contrario dodaje, że „błąd w sztuce medycznej nie oznacza zatem wszelkich przypadków, w których lekarz wadliwie się zachował, a tylko takie, kiedy ta wadliwość wiązała się z naruszeniem zasad wiedzy i praktyki medycznej" (tamże). Zwolennikiem tej koncepcji jest także W. Kulesza, określający „błąd sztuki lekarskiej” jako postępowanie lekarza niezgodne z aktualną wiedzą medyczną i powszechnie przyjętymi zasadami jej praktycznego zastosowania. W dalszej części wywodu autor zauważa ponadto, że „innym rodzajem nieostrożnego zachowania, które może mieć miejsce w trakcie leczenia chorego, niestanowiącym jednak błędu lekarskiego - błędu w sztuce, jest nieprzestrzeganie powszechnie przyjętych elementarnych norm ostrożności, których naruszenie może być stwierdzone bez odwoływania się do wiedzy i praktyki medycznej. Nieostrożność taka może prowadzić do zwykłej pomyłki polegającej np. na pomyleniu tożsamości pacjenta i zoperowaniu innego chorego, pomyleniu kończyny pacjenta i zoperowaniu nie tej, która miała być poddana operacji, pozostawieniu narzędzia chirurgicznego lub chusty w polu operacyjnym" (Wanatowska, Kulesza 1988, 25 i 26-27). W tym kierunku idzie także A. Liszewska, prezentująca zbliżoną, acz nieco poszerzoną, definicję omawianego pojęcia, wedle której „błąd w sztuce medycznej oznacza naruszenie przez lekarza (świadomego, że podejmuje czynność medyczną) obowiązujących go w konkretnym wypadku, wypracowanych na gruncie nauki i praktyki reguł postępowania zawodowego wobec dóbr prawnych w postaci życia i zdrowia człowieka, które na gruncie prawa stanowi podstawę dla stwierdzenia naruszenia obowiązku ostrożności" (Liszewska 1998, 28 i 29). Podobnie jak wcześniej cytowany autor, przyjmuje ona, że „w praktyce można wskazać wiele przypadków naruszenia reguł ostrożności, obowiązujących $\mathrm{w}$ związku $\mathrm{z}$ wykonywaniem czynności medycznych, które nie są jednak błędami w sztuce. $Z$ błędem w sztuce mamy do czynienia wówczas, gdy stwierdzenie naruszenia norm ostrożności wymaga odwołania się do wiedzy i praktyki medycznej, a nie elementarnych, powszechnie uznanych zasad postępowania” (tamże). Autorka precyzuje ponadto, że „różnica między 
naruszeniem obowiązku ostrożności stanowiącym błąd w sztuce a każdą inną nieostrożnością lekarza polega na tym, że w pierwszym wypadku stwierdzenie braku ostrożności będzie wymagało specjalistycznej wiedzy z zakresu medycyny, a zatem także odwołania się do opinii biegłych lekarzy" (tamże). Nieco szerzej omawiane pojęcie definiuje B. Popielski, zdaniem którego „błąd lekarski jest postępowaniem wbrew powszechnie uznanym zasadom wiedzy lekarskiej. [...] Chodzi tu zatem o działanie - lub zaniechanie - wbrew takim zasadom wiedzy lekarskiej, które są ogólnie przyjęte i utrwalone w medycynie, przede wszystkim praktycznej" (Popielski 1963, 252). Zatem i ten autor odwołuje się do wiedzy medycznej, akcentując przy tym jej wymiar praktyczny, choć w dalszej części cytowanej wypowiedzi dodaje on, że ,również przekroczenie obowiązujących lekarza regulaminów szpitala lub poradni może być błędem lekarskim" (tamże), co stoi w kontrze do wcześniej zaprezentowanych stanowisk, wedle których tego rodzaju naruszenia nie można określić mianem błędu medycznego, jako że do jego stwierdzenia nie jest konieczne odwołanie się do specjalistycznej wiedzy z zakresu medycyny. Przekroczenie obowiązujących lekarza regulaminów wyłącza poza zakres pojęcia błędu medycznego również M. Nesterowicz, którego wypada uznać za zdecydowanego zwolennika wąskiego rozumienia tego terminu. Autor bowiem stoi na stanowisku, że „błąd lekarski należy traktować ściśle jako postępowanie sprzeczne z powszechnie uznanymi zasadami wiedzy medycznej" (Nesterowicz 2001, 145-146). Jego zdaniem „wraz z rozwojem możliwości diagnostycznych i wiedzy medycznej błąd w sztuce lekarskiej występuje coraz rzadziej, a szkoda, której doznaje pacjent, nie jest wynikiem błędu, lecz niedbalstwa w leczeniu albo wszelkich innych uchybień lekarza, personelu medycznego bądź szpitala" (tamże). W prezentowanym przez autora ujęciu „nie jest błędem lekarskim np. źle wykonany zastrzyk, zamiana leku lub jego nieprawidłowe przyrządzenie, niewysterylizowanie instrumentów przez zobowiązany do tego personel medyczny, pozostawienie ciała obcego w polu operacyjnym, przekroczenie czasu naświetlania promieniami Roentgena, przekroczenie obowiązujących lekarza regulaminów szpitala lub poradni, niedokonanie badań pacjenta przyjętego do szpitala, odmowa czy zwłoka w udzieleniu mu koniecznej pomocy, dokonanie operacji na innym chorym lub operacji innego zdrowego organu, brak umiejętności i zręczności u lekarza, przecięcie pacjentowi przewodu żółciowego podczas operacji usunięcia pęcherzyka żółciowego, wadliwie wykonane znieczulenie, transfuzja niewłaściwej grupy krwi, niezalecanie wymaganych przez przepisy badań okulistycznych noworodka, na skutek czego rozwinęła się groźna choroba oczu - retinopatia i dziecko straciło wzrok itp. Jest to natomiast niedołożenie należytej staranności w czynnościach leczniczych, niedbalstwo lekarza lub personelu medycznego albo różnego rodzaju błędy techniczne i organizacyjne" (tamże). Autor przedstawia zatem cały katalog sytuacji, których - jego zdaniem - nie można uznać za błąd medyczny. Wśród nich znajdują się także takie przypadki - jak chociażby niedokonanie wymaganych badań, nieudzielenie koniecznej pomocy oraz wadliwe 
wykonanie znieczulenia - co do których można mieć poważne wątpliwości, czy uzasadnione jest określanie ich mianem zwykłego zaniedbania, niemającym nic wspólnego z naruszeniem wskazań aktualnej wiedzy medycznej. Takiemu podejściu sprzeciwia się T. Sroka, który wprawdzie - podobnie jak W. Kulesza, A. Liszewska i R. Kędziora - odwołuje się do pojęcia „wiedzy i praktyki medycznej”, jednakże rozumianego odmiennie. Zdaniem autora „konieczność oceny postępowania lekarza zgodnie z wymogami aktualnej wiedzy i nauki medycznej to odwołanie się do zasady udzielania świadczeń zdrowotnych zgodnie $\mathrm{z}$ aktualną wiedzą medyczna, natomiast [...] zgodność z powszechnie przyjętą praktyką lekarską to ocena postępowania lekarza z punktu widzenia prawidłowości działań leczniczych pod kątem ich prawidłowości wykonania, a zatem jest to odniesienie do zasady udzielania świadczeń zdrowotnych z należytą starannością" (Sroka 2013, 466). W jego ocenie ,za błąd medyczny, jeżeli już, należy uznać zachowanie, które jest sprzeczne $\mathrm{z}$ dwiema spośród zasad udzielania świadczeń zdrowotnych: zasadą udzielania świadczeń zdrowotnych zgodnie z aktualną wiedzą medyczną i zasadą udzielania świadczeń zdrowotnych z należytą starannością. Konsekwencją tego stanowiska jest również stwierdzenie, że nie istnieje potrzeba rozdzielania na podstawie niejasnych i płynnych kryteriów przypadków naruszenia zasady udzielania świadczeń zdrowotnych z należytą starannością na te, które stanowią błąd medyczny, oraz na te, które stanowią zwykłe zaniedbania. Przyjęcie poglądu, iż to sprzeczność $\mathrm{z}$ ową zasadą świadczy o błędzie medycznym, implikuje twierdzenie, że każde zachowanie, które nie stanowi dochowania należytej staranności, w tym także i takie, które można określić mianem zwykłego zaniedbania, stanowić będzie błąd medyczny" (tamże, 466-467). Również w przekonaniu Z. Marka „o błędzie mówimy, jeżeli lekarz postąpi niezgodnie z zasadami wiedzy, nie dołoży koniecznej staranności, przekroczy swoje kompetencje" (Marek 1999, 83), a zatem nie tylko w przypadku naruszenia zasady udzielania świadczeń zdrowotnych zgodnie z wskazaniami aktualnej wiedzy medycznej, ale także w sytuacji naruszenia innych reguł ostrożnego (starannego) postępowania.

Jak wynika z powyższego, przytoczenie wypowiedzi chociażby części autorów zajmujących się omawianą tematyką pokazuje, jak duża może być rozpiętość stanowisk prezentowanych w tym względzie. W tym miejscu warto przywołać także wybrane orzecznictwo odnoszące się do przedmiotowej problematyki. Przykładowo w wyr. z 1.4.1955 r. (IV CR 39/54, OSNCK 1957, Nr 1, poz. 7) SN uznał, że „błędem w sztuce lekarskiej jest czynność (zaniechanie) lekarza w zakresie diagnozy i terapii, niezgodna z nauką medycyny w zakresie dla lekarza dostępnym. Zaniedbania lekarza w zakresie obowiązków otoczenia chorego opieką oraz w zakresie organizacji bezpieczeństwa higieny i opieki nad chorym nie są błędem w sztuce lekarskiej”. W podobnym tonie SN wypowiedział się w wyr. z 17.2.1967 r. (I CR 435/66, OSNC 1967, Nr 10, poz. 177), w którym wyraźnie podkreślił, że ,zaniechanie polegające na niezapewnieniu pacjentowi opieki wykwalifikowanego lekarza i pozostawienie po operacji w zeszytej ranie środków 
opatrunkowych nie może być potraktowane jako błąd w sztuce lekarskiej. Zaniedbanie takie należy ocenić jako niedopełnienie ze strony ordynatora i lekarza dokonującego operacji obowiązków zachowania należytej staranności przy wykonywaniu swych funkcji. [...] Nie można zaliczyć do błędu w sztuce lekarskiej zaniedbania polegającego na naruszeniu obowiązku stosowania przy dokonywaniu operacji elementarnych zasad aseptyki, której zachowanie jest kardynalnym obowiązkiem całego personelu zatrudnionego przy przeprowadzaniu zabiegów chirurgicznych, a przy tym nie wymaga posiadania specjalnych wiadomości ani nie może nasuwać przy jej stosowaniu najmniejszych wątpliwości tak natury praktycznej, jak i teoretycznej, podobnie jak nie stanowiłoby błędu w sztuce lekarskiej podanie pacjentowi trucizny zamiast lekarstwa". Zbliżony pogląd, choć już nie tak daleko idący, zaprezentował SN w wyroku z 8.9.1973 r. (I KR 116/72, OSNKW 1974, Nr 2, poz. 26), w którym to wskazał, że „ustalenie błędu w sztuce lekarskiej zależy od odpowiedzi na pytanie, czy postępowanie lekarza w konkretnej sytuacji i z uwzględnieniem całokształtu okoliczności istniejących w chwili zabiegu, a zwłaszcza tych danych, którymi wówczas dysponował albo mógł dysponować, zgodne było z wymaganiami aktualnej wiedzy i nauki medycznej oraz powszechnie przyjętej praktyki lekarskiej”. Stanowisko to zostało następnie powtórzone przez SN w wyroku z 29.4.1994 r. (WR 70/94, OSNKW 1994, Nr 11-12, poz. 70) oraz w wyroku z 10.12.2002 r. (V KK 33/02, LEX Nr 75498). W prezentowaną linię orzeczniczą wpisuje się również wyrok z 12.2.2013 r. (II KK 124/12, LEX $\mathrm{Nr}$ 12777697), w którym SN stanął na stanowisku, że „dla prawidłowego rozważenia odpowiedzialności karnej lekarza za przestępstwo przeciwko życiu i zdrowiu pacjenta niezbędne jest ustalenie, czy czynności lecznicze zostały wykonane zgodnie z zasadami wiedzy i sztuki medycznej, a więc czy lekarz dopuścił się błędu w sztuce lekarskiej”.

\section{BLĄD MEDYCZNY A REGULY OSTROŻNOŚCI WYMAGANE W PROCESIE LECZENIA}

Analiza przybliżonego dorobku literatury i orzecznictwa skłania do wniosku, że prezentowane na tym gruncie koncepcje, pomimo swojego zróżnicowania, wskazują na wspólny kierunek myślenia ich autorów, wedle którego błędem medycznym jest generalnie zachowanie sprzeczne $z$ regułami postępowania medycznego. Stąd wypada w tym miejscu przybliżyć, jak na gruncie prawa karnego rozumiane jest pojęcie zasad postępowania z dobrem prawnym, albo inaczej-reguł ostrożności. Nie wchodząc głębiej w problematykę ich miejsca w strukturze przestępstwa, która z racji swej złożoności zasługuje na odrębne potraktowanie, warto wskazać, że zgodnie z koncepcją wielowarstwowej struktury przestępstwa, prezentowaną przez A. Zolla, warunkiem odpowiedzialności karnej jest ustalenie, że doszło do popełnienia czynu bezprawnego - naruszającego normę sankcjonowaną, 
przy braku okoliczności uzasadniających wyłączenie bezprawności, karalnego - realizującego znamiona typu czynu zabronionego pod groźbą kary, przy braku okoliczności uzasadniających wyłączenie karalności, karygodnego - którego stopień społecznej szkodliwości jest większy niż znikomy, oraz zawinionego - popełnionego w okolicznościach, w których sprawcy można zarzucić, że „w czasie swego bezprawnego, karalnego i karygodnego czynu nie dał posłuchu normie prawnej, chociaż można było podporządkowania normie prawnej od sprawcy wymagać" (Zoll 2012, 44-57). Z kolei warunkiem sprzeczności zachowania z normą sankcjonowaną jest naruszenie bądź narażenie na niebezpieczeństwo dobra prawnego, przy jednoczesnym naruszeniu zasad postępowania $\mathrm{z}$ tym dobrem ${ }^{18}$. Naruszenie reguł ostrożności ma szczególne znaczenie dla ustalania bezprawności czynów charakteryzujących się nieumyślnością, jako że stanowi jedną z jej ustawowych przesłanek. Zgodnie bowiem z art. $9 \S 2$ k.k. czyn zabroniony popełniony jest nieumyślnie, jeśli sprawca nie mając zamiaru jego popełnienia, popełnia go jednak na skutek niezachowania ostrożności wymaganej w danych okolicznościach, mimo że możliwość popełnienia tego czynu przewidywał albo mógł przewidzieć. Warto przy tym wyjaśnić, że ,jakkolwiek uregulowanie zawarte $\mathrm{w}$ art. $9 \S 2 \mathrm{k} . \mathrm{k}$. nie mówi o zasadach czy też regułach ostrożności, to oczywiste wydaje się, że sprawca, który nie zachowuje ostrożności, narusza pewne zasady. Przepis ten należy zatem rozumieć $\mathrm{w}$ ten sposób, iż chodzi w nim w istocie o naruszenie pewnych reguł postępowania, których przestrzeganie zapewniać ma bezpieczeństwo dobru, do którego dana reguła się odnosi" (Lachowski 2013, 570). Należy także wskazać na zasadniczą rolę reguł ostrożności na gruncie przestępstw znamiennych skutkiem, którego przypisanie warunkowane jest m.in. naruszeniem reguły postępowania, zabezpieczającej przed nastąpieniem skutku ${ }^{19}$. W doktrynie prawa karnego przyjmuje się, że reguły ostrożności zakreślają granice społecznie dopuszczalnego ryzyka, określają, jakie zachowania należy podjąć, a jakich zaniechać w kontaktach $\mathrm{z}$ danym dobrem, aby zminimalizować niebezpieczeństwo jego narażenia lub naruszenia, wyznaczając tym samym zakres dozwolonych zachowań ryzykownych ${ }^{20}$. Ustalenie poziomu dopuszczalnego ryzyka jest szczególnie istotne w odniesieniu do działalności leczniczej, która w założeniu wiąże się $\mathrm{z}$ ryzykiem zaistnienia ujemnych następstw ${ }^{21}$. Ocena, czy dane zachowanie mieści się $\mathrm{w}$ ramach zakreślonego regułami ostrożności obszaru zachowań społecznie akceptowalnych, czy też narusza wyznaczone w tym obszarze reguły ostrożnego postępowania, stanowi kwestię fundamentalną dla wyznaczenia granicy pomiędzy błędnie a poprawnie dokonaną czynnością leczniczą, także tą zakończoną niepowodzeniem z powodu ziszczenia się ryzyka niepowodzenia, które towarzyszy

${ }^{18}$ Tak: Zoll (2012, 48); Wróbel, Zoll (2014, 171).

${ }^{19}$ Tak: Zoll (1988, 49); Dębski (1995, 180).

${ }^{20}$ Tak: Zoll (2012, 154-155); Wróbel, Zoll (2014, 174); Dębski (1995, 132 i n.).

${ }^{21}$ Szerzej na temat ryzyka w związku z wykonywaniem czynności medycznych pisze Radzicki (1967). 
nawet prawidłowo udzielanym świadczeniom zdrowotnym (Plebanek 2010, 50). Dokonujący jej lekarz tylko wtedy realizuje znamiona przestępstwa nieumyślnego, gdy dopuszcza się naruszenia obiektywnego obowiązku ostrożności. Innymi słowy, brak takiego naruszenia wyłącza realizację znamion typu i czyni konkretne zachowanie irrelewantnym z punktu widzenia prawa karnego (Zoll 1988, 43). Zatem zachowanie lekarza zgodne $\mathrm{z}$ regułami ostrożności wymaganymi $\mathrm{w}$ danych okolicznościach, nawet jeśli doprowadzi do narażenia dobra prawnego w postaci życia i zdrowia pacjenta lub wręcz do naruszenia takiego dobra, nie będzie mogło być uznane za zachowanie bezprawne, a tym samym za zachowanie karalne, co w konsekwencji wykluczy także możliwość ustalenia kolejnych przesłanek odpowiedzialności karnej, którymi są karygodność i zawinienie (Zoll 2012, 43-46 i 153). Na koniec tej części rozważań należy wyraźnie podkreślić, że choć reguły ostrożności stanowią kategorię obiektywną, to należy odnosić je zawsze do konkretnego przypadku, zgodnie z kodeksową formułą „ostrożności wymaganej w danych okolicznościach".

Przechodząc do oceny relacji między błędem medycznym a naruszeniem reguł ostrożności, należy na wstępie rozstrzygnać, czy błędem medycznym jest zachowanie sprzeczne z abstrakcyjnym wzorcem postępowania, czy też właściwym konkretnej sytuacji. Wedle pierwszej koncepcji, mimo uznania zachowania osoby udzielającej świadczenia zdrowotnego za błąd medyczny, do stwierdzenia naruszenia reguł ostrożności wymaganych w danych okolicznościach konieczne jest ponadto ustalenie, że w konkretnym przypadku doszło do niedopełnienia obowiązku ostrożności, jako że w tym ujęciu błąd medyczny ustalany jest w oderwaniu od okoliczności danej sprawy. Zgodnie z drugą koncepcją ustalenie, że doszło do popełnienia błędu medycznego, możliwe jest wyłącznie na gruncie konkretnej sytuacji, a co za tym idzie jego stwierdzenie przesądza równocześnie o naruszeniu ostrożności wymaganej w danych okolicznościach. Przyjęcie, że błędem medycznym jest naruszenie zasad postępowania w odniesieniu do aktualnych warunków - co w konsekwencji oznacza, że stwierdzenie jego popełnienia jest podstawą do uznania, że nastąpiło również naruszenie reguł ostrożności wymaganych w konkretnych okolicznościach - aktualizuje z kolei konieczność oceny, czy każde przekroczenie owych reguł będzie mogło być określone mianem błędu medycznego. W zdecydowanej większości stanowisk, zaprezentowanych w literaturze i orzecznictwie, opowiedziano się za tym, że w granicach pojęcia błędu medycznego mieszczą się wyłącznie takie sytuacje, w których wadliwe postępowanie lekarza wynika z niedochowania reguł „nauki medycznej”, „wiedzy i sztuki medycznej” bądź „wiedzy i praktyki medycznej”. Określenia te zdają się wskazywać na tylko jedną odmianę reguł ostrożności - której naruszenie może być kwalifikowane jako błąd medyczny - stanowiącą treść ogólnej zasady udzielania świadczeń zdrowotnych zgodnie z aktualną wiedzą medyczną. Autorzy rozumiejący błąd medyczny jako naruszenie reguł ostrożności mających podstawę w wiedzy i praktyce medycznej, wśród nich W. Kulesza, A. Liszewska, 
M. Nestorowicz i R. Kędziora, wyraźnie wyłączają z zakresu tej kategorii spraw wszelkie inne przypadki nieprzestrzegania obowiązujących lekarza zasad postępowania zawodowego, których naruszenie może być stwierdzone bez odwoływania się do wiedzy specjalistycznej, np. pozostawienie ciała obcego w polu operacyjnym. Odmienne spojrzenie prezentuje jednak T. Sroka, zdaniem którego „konieczność oceny postępowania lekarza zgodnie z wymogami aktualnej wiedzy i nauki medycznej to odwołanie się do zasady udzielania świadczeń zdrowotnych zgodnie z aktualną wiedzą medyczną, natomiast [...] zgodność z powszechnie przyjętą praktyką lekarską to ocena postępowania lekarza z punktu widzenia prawidłowości działań leczniczych pod kątem ich prawidłowości wykonania, a zatem jest to odniesienie do zasady udzielania świadczeń zdrowotnych z należyta starannością" (Sroka 2013, 466). Autor ten, podobnie zresztą jak Z. Marek, stoi na stanowisku, że pojęcie błędu medycznego powinno obejmować, poza naruszeniem reguł wynikających ze wskazań aktualnej wiedzy medycznej, także i naruszenie wymogu dochowania należytej staranności przy ich stosowaniu w praktyce zawodowej, a rozdzielanie przypadków naruszenia zasady udzielania świadczeń zdrowotnych z należytą starannością na te, które stanowią błąd medyczny, oraz na te, które stanowią zwykłe zaniedbania - uważa za niezasadne. Przyznając słuszność takiemu wyznaczeniu ram pojęcia błędu medycznego, aby obejmowały one jedynie przypadki naruszenia wskazań aktualnej wiedzy medycznej, poza ich granicami pozostawia się wiele innych reguł ostrożności obowiązujących lekarza w codziennej praktyce udzielania świadczeń zdrowotnych, których niedochowanie może prowadzić do analogicznych skutków, jak niezastosowanie się do wskazań aktualnej wiedzy medycznej, a w konsekwencji może mieć wpływ na przypisanie odpowiedzialności karnej. „Każda bowiem sytuacja stanowiąca naruszenie reguł postępowania $\mathrm{z}$ dobrem prawnym, niezależnie od tego, czy zostanie uznana za błąd medyczny, czy za zwykłe zaniedbanie, będzie mogła być podstawa przypisania skutku" (tamże, 465). Przemawiałoby to za odrzuceniem definicji błędu medycznego obejmującej jedynie takie sytuacje, w których wadliwe postępowanie lekarza wynika z naruszenia wskazań aktualnej wiedzy medycznej oraz opowiedzeniem się za definicją poszerzoną o aspekt należytej staranności. Nasuwa się jednak pytanie, czy błąd medyczny w szerszym ujęciu można uznać za pojęcie kompleksowe, a zatem na tyle pojemne, aby można było odnieść je do wszystkich zasad postępowania obowiązujących lekarza w procesie leczenia. Nie ulega wątpliwości, że błąd medyczny w pierwszym ujęciu jest pojęciem znacznie węższym niż naruszenie reguł ostrożności, wydaje się jednak, że istnieje szereg reguł ostrożności, których nie obejmie nawet szersza definicja błędu medycznego. Warto mieć bowiem na uwadze, że „reguły ostrożności charakteryzowane są przez trzy elementy: sprawca ma mieć odpowiednie kwalifikacje do przeprowadzenia określonej czynności, pozostającej w związku z chronionym dobrem; czynność ma być przeprowadzona przy użyciu odpowiedniego dla niej narzędzia; czynność ma być przeprowadzona w odpowiedni sposób, tzn. 
taki, który nie zwiększa ryzyka dla chronionego dobra, ponad stopień uznany za dopuszczalny ze względu na społecznie istotny sens przeprowadzanej czynności” (Zoll 1990, 35). Przyjmując, że elementy te wyznaczają granice poszczególnych kategorii reguł ostrożności, należy ocenić, że poza zakresem desygnatów pojęcia błędu medycznego - rozumianego jako naruszenie zasad postępowania mających podstawę w wiedzy medycznej i wymogu należytej staranności, stosownie do wskazań szerszej definicji - pozostaną przypadki naruszenia reguł z pierwszej i drugiej kategorii, odnoszących się do kwalifikacji podmiotu i używanego narzędzia. Pojęcie błędu medycznego można co prawda powiązać z regułami należącymi do trzeciej kategorii, odnoszącej się do sposobu postępowania z dobrem prawnym, ale jak się wydaje - nie ze wszystkimi, a co najwyżej z niektórymi ich odmianami. Poza kryteriami oceny, czy doszło do popełnienia błędu medycznego, zdają się pozostawać chociażby przynależne tej kategorii zasady zespołowego działania w procesie udzielania świadczeń zdrowotnych, które - jako że odnoszą się raczej do właściwej organizacji niż wiedzy i praktyki medycznej w ścisłym tego słowa znaczeniu - znajdą się poza ramami pojęcia błędu medycznego. Musi to prowadzić do wniosku, że błąd medyczny nawet w najszerszym prezentowanym w literaturze i orzecznictwie ujęciu może służyć do określenia naruszenia co najwyżej odmiany spośród całego szeregu reguł ostrożności, które obowiązują lekarza w codziennej praktyce zawodowej.

\section{OCENA PRZYDATNOŚCI STOSOWANIA POJĘCIA BŁĘDU MEDYCZNEGO NA POTRZEBY USTALENIA ODPOWIEDZIALNOŚCI KARNEJ ZA NEGATYWNE SKUTKI DLA ŻYCIA I ZDROWIA PACJENTA}

Mając na uwadze dotychczasowe rozważania, należy ocenić, że zbyt wąski zakres pojęcia błędu medycznego może czynić go nieprzydatnym z punktu widzenia ustalania odpowiedzialności karnej za negatywne skutki dla życia i zdrowia pacjenta powstałe $\mathrm{w}$ procesie leczenia. Istnieje bowiem cały szereg reguł postępowania odnoszących się do udzielania świadczeń zdrowotnych, których naruszenie może być podstawą przypisania skutku przestępnego. W praktyce medycznej nie mniej istotne niż wskazania aktualnej wiedzy i praktyki medycznej bywają bowiem liczne przepisy o charakterze porządkowym, których celem jest zagwarantowanie bezpieczeństwa i higieny udzielanych świadczeń zdrowotnych oraz prawidłowej ich organizacji (Kubiak 2012, 325-326). Wobec właściwej współczesnej medycynie złożoności procesu udzielania świadczeń zdrowotnych - niejednokrotnie wymagających wykonywania czynności leczniczych w wieloosobowych zespołach bądź wieloetapowo, z użyciem nowych technologii medycznych, $\mathrm{w}$ tym złożonej aparatury - w coraz większym stopniu pomyślny wynik leczenia zależy od rozwiązań mających uchronić przed uchybieniami właśnie o charakterze technicznym lub organizacyjnym. Rozwój nauk medycznych pociaga za sobą 
niestety nie tylko poszerzenie spektrum możliwości terapeutycznych, ale także i katalogu reguł ostrożności, których naruszenie stanowi podstawę dla przypisania negatywnego skutku powstałego w procesie leczenia, a wśród nich również tych regulujących wymogi, którym powinny odpowiadać pod względem fachowym i sanitarnym pomieszczenia i urządzenia podmiotów wykonujących działalność leczniczą oraz organizację procesu udzielanych tam świadczeń zdrowotnych. Jeśli zatem na potrzeby odpowiedzialności karnej należy zbadać prawidłowość zachowania osoby udzielającej świadczeń zdrowotnych z punktu widzenia całości obowiązujących ją w danej sytuacji reguł ostrożności, to wydaje się zabiegiem sztucznym wyodrębnianie następnie w ramach katalogu niedochowanych zasad tych, których niedopełnienie może być określone mianem błędu medycznego. Skoro można poprzestać na ustaleniu naruszenia obowiązku ostrożności, to pojęcie błędu medycznego staje się zbędne i nie znajduje uzasadnienia wyszczególnianie go w ramach szerszej kategorii, którą jest naruszenie ostrożności wymaganej w danych okolicznościach. Skłania to do opowiedzenia się za rezygnacją z posługiwania się pojęciem błędu medycznego na rzecz naruszenia reguł ostrożności ${ }^{22}$. Nie jest to jednak jedyny argument przemawiający za zaniechaniem odwoływania się do tego pojęcia na gruncie prawa karnego. Należy pamiętać, że w istocie lekarz odpowiada nie za błąd medyczny, a co najwyżej za jego skutek. Odpowiedzialność karna osób udzielających świadczeń zdrowotnych za spowodowanie negatywnych następstw dla życia i zdrowia pacjenta w procesie leczenia, wobec braku odrębnych typów czynów zabronionych penalizujących tego rodzaju zachowania ${ }^{23}$, uzależniona jest od wypełnienia znamion jednego z typów przestępstw skutkowych, charakteryzujących się nieumyślnością, takich jak nieumyślne spowodowanie śmierci (art. 155 k.k.), nieumyślne spowodowanie ciężkiego uszczerbku na zdrowiu (art. 156 § 2 k.k.), nieumyślne spowodowanie średniego albo lekkiego uszczerbku na zdrowiu (art. 157 § 3 k.k.), bądź nieumyślne narażenie na niebezpieczeństwo utraty życia albo ciężkiego uszczerbku na zdrowiu (art. 160 § 3 k.k.) $)^{24}$. Warto wskazać, nie wchodząc jednak głębiej w tę złożoną problematykę, że ,podstawą odpowiedzialności karnej za przestępstwa skutkowe jest ustalenie, że w określonym stanie faktycznym wystapiła taka zmiana rzeczywistości, która odpowiada desygnatom skutku stanowiącego znamię określonego

${ }^{22} \mathrm{~W}$ tym tonie wypowiadają się także: Sośniak (1968, 64-100); Rejman (1975, 1078 i n.); Zoll (1988, 53-54); Boratyńska, Konieczniak (1999, 55); Filar (2000, 108).

${ }^{23}$ Szerzej na temat stworzenia odrębnej regulacji penalizującej błąd medyczny piszą: Rejman (1991, 36-37); Liszewska (1998, 45-54).

${ }^{24}$ Oczywiście nie można wykluczyć wystąpienia sytuacji, w której lekarz swoim zachowaniem zrealizowałby znamiona typu umyślnego czynu zabronionego, co więcej historia medycyny zna takie przypadki, jednakże na potrzeby niniejszej publikacji przyjęto, że co do zasady lekarz działa w celu ratowania dóbr prawnych, jakimi są życie i zdrowie, nie zaś z zamiarem narażenia ich na niebezpieczeństwo bądź naruszenia, a ewentualne negatywne skutki dla życia i zdrowia pacjenta, powstałe w miejsce lub obok zamierzonego stanu rzeczy, nie są przez niego objęte umyślnością. 
typu czynu zabronionego. Stwierdzenie z kolei zaistnienia w stanie faktycznym określonego skutku powoduje konieczność ustalenia, że dana osoba może być uznana za sprawcę owej zmiany rzeczywistości w rozumieniu prawa karnego. Dla stwierdzenia sprawstwa jest konieczne wykazanie odpowiedniej więzi łączącej czyn sprawcy z zaistniałym skutkiem, zaś podstawą ustalenia tej więzi jest tzw. obiektywne przypisanie skutku" (Sroka 2013, 40). Z punktu widzenia omawianej problematyki dla przypisania skutku wystarczające jest ustalenie, że w konkretnej sytuacji doszło do naruszenia normy zakazującej powodowania skutku lub nakazującej zapobieganie skutkowi poprzez m.in. wykazanie, że doszło do naruszenia reguł ostrożności - bez znaczenia jest zaś, czy dany przypadek naruszenia reguł ostrożności zostanie określony mianem błędu medycznego, niezależnie od przyjętej definicji. Podobnie będzie na gruncie ustalania przesłanek nieumyślności, dla którego konieczne jest wykazanie, że choć sprawca czynu możliwość taką przewidywał albo mógł przewidzieć, popełnił czyn zabroniony w wyniku naruszenia reguł ostrożnego postępowania, obowiązujących go w danych okolicznościach. I w tym przypadku bez znaczenia pozostaje, czy ich niedochowanie można zakwalifikować jako błąd medyczny. Należy zatem w pełni zgodzić się ze stanowiskiem prezentowanym przez T. Srokę, który sprzeciwia się uznaniu błędu medycznego za odrębną przesłankę odpowiedzialności karnej za przestępstwa skutkowe popełnione w związku z udzielaniem świadczeń zdrowotnych. Autor trafnie wskazuje, że błąd medyczny nie może być traktowany jako dodatkowy, szczególny warunek odpowiedzialności karnej, prowadzący do modyfikacji zasad odpowiedzialności karnej lekarza za przestępstwa przeciwko życiu i zdrowiu (Sroka 2013, 473). Niepokojąco często w praktyce wymiaru sprawiedliwości zdarzają się jednak sprawy, w których uznaje się konkretne okoliczności za niezawierające się w zakresie błędu medycznego, przy jednoczesnym założeniu, że tylko błąd medyczny może prowadzić do odpowiedzialności karnej, mimo że nawet zwolennicy posługiwania się tym pojęciem podkreślają, że podstawą odpowiedzialności karnej może być naruszenie także innych reguł ostrożności niż te mieszczące się w pojęciu błędu medycznego ${ }^{25}$. Tym samym poza zakresem odpowiedzialności karnej pozostawia się przypadki naruszenia reguł ostrożności, które nie są kwalifikowane jako błąd medyczny, chociaż mogą stanowić podstawę przypisania skutku. Słusznie podnosi on ponadto, że „uznanie błędu medycznego jako przesłanki odpowiedzialności karnej za negatywne skutki dla życia i zdrowia pacjenta wymagałoby jednoczesnego ustalenia zakresu sytuacji, które stanowiłyby ów błąd, w celu zapewnienia identyczności rozstrzygnięć w podobnych przypadkach" (tamże). Niejednolite rozumienie tego pojęcia może bowiem prowadzić do różnych wniosków w podobnych sprawach, a w konsekwencji do stosowania niejednolitych kryteriów ustalania odpowiedzialności karnej osób udzielających

${ }^{25}$ Zob. wyniki analizy praktyki wymiaru sprawiedliwości w tym przedmiocie, przedstawione przez: Sroka (2013, 473-483). 
świadczeń zdrowotnych. Nie przekonują z kolei argumenty przeciwne, wskazujące na przydatność pojęcia błędu medycznego jako ułatwiającego orzekanie w sprawach karnych. Rozważanie odpowiedzialności karnej przez pryzmat kryteriów błędu medycznego, pojęcia nieścisłego i niejednolicie rozumianego, implikuje liczne wątpliwości i niepotrzebnie mnoży problemy interpretacyjne, zaciemniając tylko obraz sytuacji prawnokarnej w już i tak skomplikowanych sprawach tego typu. Podobnie nie może stanowić wystarczającego uzasadnienia posługiwania się pojęciem błędu medycznego na gruncie prawa karnego okoliczność, że jest ono zakorzenione w literaturze, opiniach biegłych, praktyce wymiaru sprawiedliwości oraz świadomości społecznej, skoro zasady odpowiedzialności karnej nie warunkują jej ustalenia wystąpieniem błędu medycznego. Wydaje się więc, że posługiwanie się tym terminem jest jedynie kwestią przyjętej na przestrzeni ostatnich lat konwencji, nie ma ono jednak praktycznego znaczenia dla rozstrzygania postępowań sądowych dotyczących odpowiedzialności karnej za negatywne skutki dla życia i zdrowia pacjenta powstałe w procesie leczenia. Pojęcie to jest zatem do zaakceptowania tylko w sferze języka potocznego, na potrzeby identyfikacji w opinii publicznej okoliczności zdarzenia z określoną kategorią spraw.

\section{BIBLIOGRAFIA}

Baran, Erazm. 1996. „Przesłanki odpowiedzialności karnej lekarzy w sprawach o błąd lekarski”. Archiwum Medycyny Sadowej i Kryminologii 47: 253-259.

Boratyńska, Maria, Przemysław Konieczniak. 1999. „Naruszenie zasad ostrożności jako przesłanka odpowiedzialności cywilnej, karnej i zawodowej lekarza”. Prawo i Medycyna 3: 46-57.

Buchała, Kazimierz. 1963. „Przestrzeganie zasad ostrożności - problem bezprawności czy winy”. Państwo i Prawo 7: 84-92.

Buchała, Kazimierz. 1974. „Glosa do wyroku SN z dnia 16 stycznia 1974 r. (III KR 311/73)”. Nowe Prawo 11: 1583-1586.

Cyprian, Tadeusz, Paweł Asłanowicz. 1949. Karna i cywilna odpowiedzialność lekarza. Kraków: Księgarnia Wydawnicza Dr L.J. Jaroszewski.

Dębski, Ryszard. 1995. Pozaustawowe znamiona przestępstwa. Łódź: Wydawnictwo Uniwersytetu Łódzkiego.

Filar, Marian. 2000. Lekarskie prawo karne. Kraków: Zakamycze.

Grzywo-Dą̧rowski, Wiktor. 1958. Odpowiedzialność karna lekarza w zwiqzku z wykonywaniem pracy zawodowej. Warszawa: Państwowy Zakład Wydawnictw Lekarskich.

Kędziora, Renata. 2009. Odpowiedzialność karna lekarza w zwiqzku z wykonywaniem czynności medycznych. Warszawa: Wolters Kluwer.

Kubiak, Rafał. 2012. Odpowiedzialność karna za wykonywanie zabiegów kosmetycznych. Kraków: Medycyna Praktyczna.

Lachowski, Jerzy. 2013. „Przestępstwo i jego struktura. Bezprawność”. W System prawa karnego. Nauka o przestępstwie. Zasady odpowiedzialności. T. 3. Red. Ryszard Dębski. Warszawa: Wydawnictwo C. H. Beck.

Liszewska, Agnieszka. 1994. „Wątpliwości wokół pojęcia błędu w sztuce lekarskiej”. Acta Universitatis Lodziensis. Folia Iuridica 60: 129-138.

Liszewska, Agnieszka. 1998. Odpowiedzialność karna za bład w sztuce lekarskiej. Kraków: Zakamycze. 
Marek, Zdzisław. 1999. Bład medyczny. Kraków: Krakowskie Wydawnictwo Medyczne.

Nesterowicz, Mirosław. 2001. Prawo medyczne. Toruń: Wydawnictwo Dom Organizatora.

Plebanek, Ewa. 2010. „Odpowiedzialność karna lekarza za przestępstwa przeciwko życiu i zdrowiu w aspekcie leczenia za pomocą nierozpowszechnionych lub nowatorskich metod terapeutycznych". Prawo i Medycyna 39: 48-67.

Popielski, Bolesław. 1963. Medycyna i prawo. Warszawa: Państwowy Zakład Wydawnictw Lekarskich.

Radzicki, Józef. 1967. Ryzyko zabiegów lekarskich w prawie karnym. Warszawa: Państwowy Zakład Wydawnictw Lekarskich.

Rejman, Genowefa. 1975. „Przegląd orzecznictwa Sądu Najwyższego w zakresie prawa karnego materialnego". Nowe Prawo 7-8: 1063-1086.

Rejman, Genowefa. 1991. Odpowiedzialność karna lekarza. Warszawa: Wydawnictwo Uniwersytetu Warszawskiego.

Ruff, Jan. 1929. Odpowiedzialność karna lekarza. Warszawa: Księgarnia F. Hoesicka.

Sawicki, Jerzy. 1954. „O odpowiedzialności za błędny zabieg medyczny. Problem winy”. Państwo i Prawo 6: 991-1016.

Sawicki, Jerzy. 1958. „Odpowiedzialność karna lekarza za błąd sztuki lekarskiej”. W Odpowiedzialność karna lekarza w zwiazku z wykonywaniem pracy zawodowej. Red. Wiktor Grzywo-Dąbrowski. Warszawa: Państwowy Zakład Wydawnictw Lekarskich.

Sawicki, Jerzy. 1965. Bład sztuki przy zabiegu leczniczym w prawie karnym. Warszawa: Państwowe Wydawnictwo Naukowe.

Sośniak, Mieczysław. 1968. Cywilna odpowiedzialność lekarza. Warszawa: Wydawnictwo Prawnicze.

Sroka, Tomasz. 2013. Odpowiedzialność karna za niewłaściwe leczenie. Warszawa: Wolters Kluwer. Wachholz, Leon. 1925. Medycyna sqdowa. Kraków: Gebethner i Wolff.

Wanatowska, Wiesława, Witold Kulesza. 1988. Odpowiedzialność prawna lekarza. Warszawa: Wydawnictwo Prawnicze.

Wróbel, Włodzimierz, Andrzej Zoll. 2014. Polskie prawo karne. Kraków: Wydawnictwo Znak.

Zoll, Andrzej (red.). 2012. Kodeks karny. Część ogólna. T. 1. Komentarz do art. 1-116 k.k. Warszawa: Wolters Kluwer.

Zoll, Andrzej. 1988. Odpowiedzialność karna lekarza za niepowodzenie w leczeniu. Warszawa: Wydawnictwo Prawnicze.

Zoll, Andrzej. 1990. „Ogólne zasady odpowiedzialności karnej w projekcie kodeksu karnego”. Państwo i Prawo 10: 30-42.

Aleksandra Dabek

\section{CONSIDERATION GIVEN TO USEFULNESS OF THE CONCEPT OF A MEDICAL ERROR TO DETERMINE CRIMINAL RESPONSIBILITY OF A PHISICIAN FOR EFFECTS CREATED IN TREATMENT PROCESS AND ADVERSE TO A PATIENT'S LIFE AND HEALTH}

\footnotetext{
Abstract. The purpose of the article is to present evolution of a medical error definition, including various opinions and interpretation doubts which appear around this issue as well as to judge whether the term is useful for determining criminal responsibility of a physician for causing negative effects to a patient's life and health as a result of treatment procedure. The consideration concentrates on two areas, namely presenting views on the medical error from literature and
} 
jurisdiction as well as locating the concept of the medical error in the structure of a substantive offence committed unintentionally. The assessment particularly concerns the relationship between the medical error and the violation of rules of appropriate conduct with legal good against an offence committed unintentionally called violation of prudence rules required under some circumstances. At the end of the paper there are presented arguments against recognizing the medical error as a separate factor of criminal responsibility for perpetration of a substantive offence committed unintentionally in the process of providing health services as well as reasons for replacing the term "medical error" by a concept of a wider category, namely "violation of rules of prudence required under some circumstances".

Keywords: medical error, rules of prudence, present medical knowledge, criminal responsibility of physicians, health services. 